\title{
Science for the Stewardship of the Groundwater Resources of Cape Cod, Massachusetts
}

\section{Introduction}

Groundwater is the sole source of drinking water and a major source of freshwater for domestic, industrial, and agricultural uses on Cape Cod, Massachusetts. Groundwater discharged from aquifers also supports freshwater pond and stream ecosystems and coastal wetlands. Six hydraulically distinct groundwater-flow systems (lenses) have been delineated on Cape Cod (figs. 1 and 2). Of the approximately 450 million gallons per day of water that enters these lenses as recharge from precipitation, about 69 percent discharges directly to the coast, about 24 percent discharges to streams, and almost 7 percent is withdrawn by public-supply wells (Masterson and Walter, 2009). In most areas, groundwater in the sand and gravel aquifers is shallow and susceptible to contamination from anthropogenic sources and saltwater intrusion. Continued land development and population growth on Cape Cod have created concerns that potable water will become less available and that the quantity and quality of water flowing to natural discharge areas such as ponds, streams, and coastal waters will continue to decline.

The U.S. Geological Survey (USGS) has been investigating groundwater and surface-water resources on Cape Cod for more than 50 years. Recent studies highlighted in this fact sheet have focused on the sources of water to public-supply wells, ponds, streams, and coastal areas; the transport and discharge of nitrogen derived from domestic and municipal disposal of wastewater; and the effects of climate change on groundwater and surface-water resources. Other USGS activities include long-term monitoring of groundwater and pond levels and field research on groundwater contamination at the USGS Cape Cod Toxic Substances Hydrology Research Site (http://ma.water. usgs.gov/MMRCape/) near the Joint Base Cape Cod (JBCC), formerly the Massachusetts Military Reservation.

\section{Sources of Groundwater to Public-Supply Wells}

Cape Cod has seen rapid population growth during the past several decades; the year-round population more than doubled between 1970 and 2010. This growth has led to increased demands on water resources and concerns about declines in water quality. A sound scientific understanding of the groundwater hydrology of Cape Cod is essential for managing its freshwater resources. Determinations of the sources of groundwater to pumping wells and natural discharge areas are

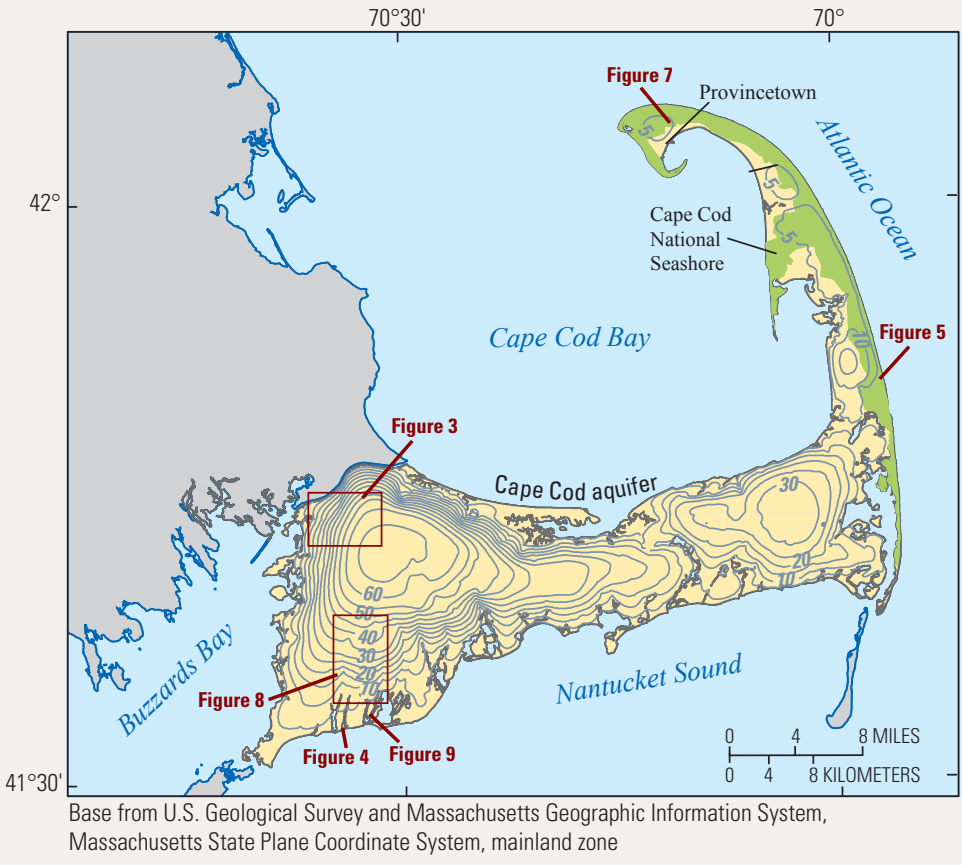

ssachusetts State Plane Coordinate System, mainland zone

\section{EXPLANATION}

-10 - Line of equal simulated water level-in feet above National Geodetic Vertical Datum of 1929 Contour interval is variable

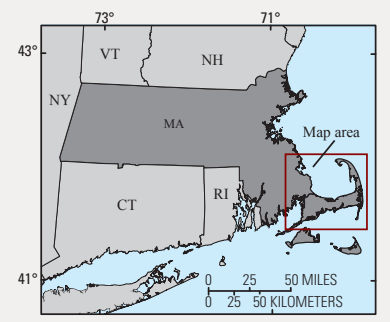

Figure 1. Location of Cape Cod, Massachusetts, and simulated water-table contours in the Cape Cod aquifer system for hydrologic and water-use conditions from 2000 through 2005. The water table in these unconfined sand and gravel aquifers forms a series of mounds that range in altitude from about 6 to 70 feet above sea level. Groundwater flows radially outward from the top of each mound toward the coast. Figure modified from Masterson and Walter (2009).

critical to this scientific understanding. In unconfined aquifer systems, in which the water table is the upper boundary of the saturated zone, the sources of groundwater are determined by groundwater recharge areas, which are the unique areas at the water table that contribute water to individual wells, streams, 


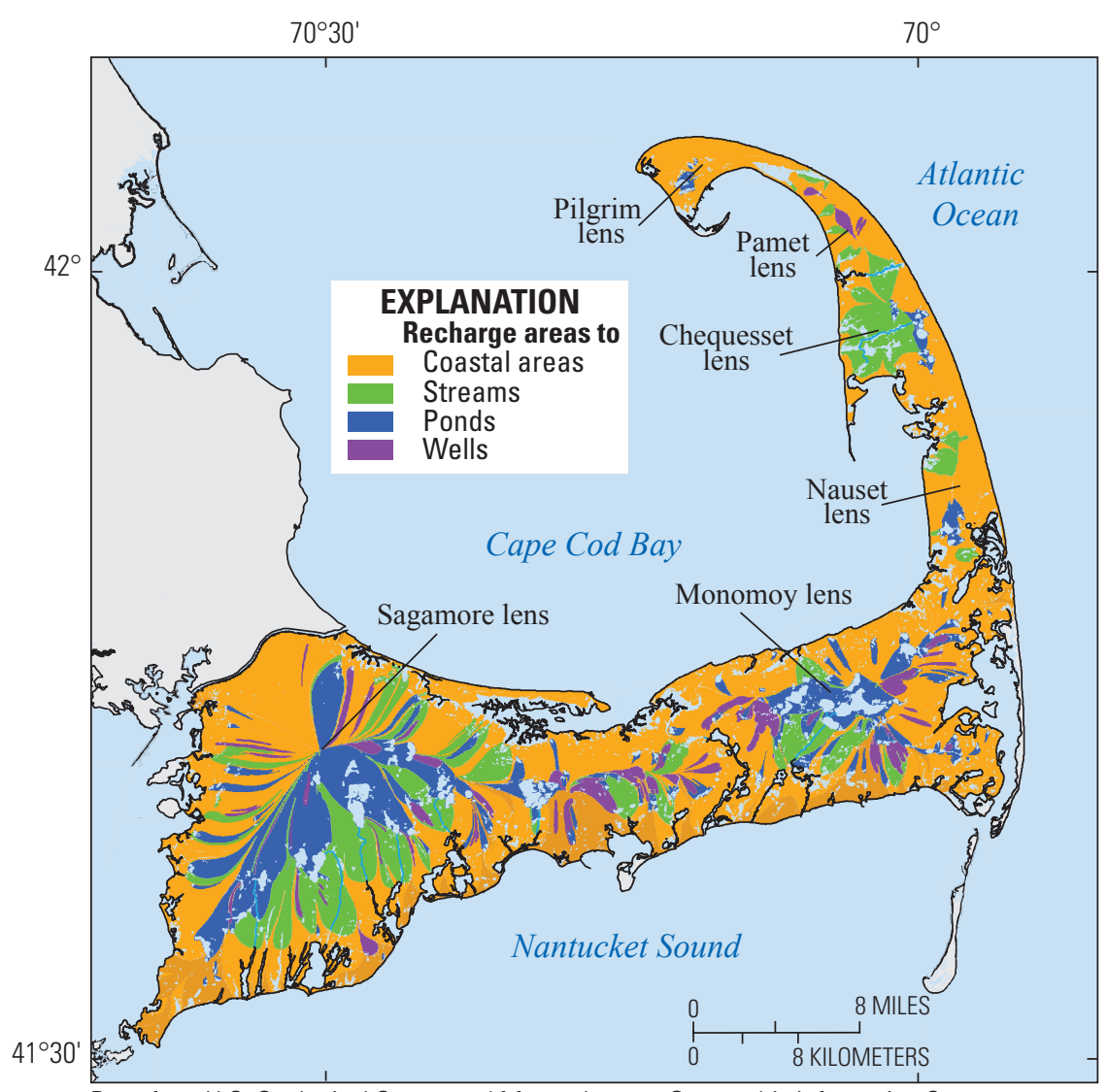

Base from U.S. Geological Survey and Massachusetts Geographic Information System, Massachusetts State Plane Coordinate System, mainland zone

Figure 2. Simulated groundwater recharge areas on Cape Cod, Massachusetts, delineated by the use of numerical groundwater-flow models for average pumping and recharge conditions from 2000 through 2005. The sizes and shapes of these areas can change in response to changes in pumping and recharge conditions. Figure modified from Masterson and Walter (2009). ponds, and coastal waters (fig. 2). Groundwater recharge areas are affected by pumping and recharge stresses on the aquifer. Changes in these stresses can result in changes to groundwater-flow rates and directions, thereby altering recharge areas and traveltimes and potentially affecting the quantity and quality of water discharging to surface water and public-supply wells.

A series of USGS studies has delineated recharge areas to public-supply wells and natural discharge areas and determined the effects of pumping wells on groundwater and pond levels, streamflows, and rates of discharge to coastal waters (http://ma.water.usgs.gov/projects/capegwresources/). In most of these studies, regional groundwater-flow models were developed to delineate recharge areas to these features under current and potential future pumping scenarios. These studies have demonstrated that small shifts in hydraulic gradients caused by changes in rates of groundwater pumping or recharge can significantly affect flow directions and, consequently, the sources of water to public-supply wells and natural discharge areas. The regional groundwater-flow models have proven to be useful tools for water-resource managers, State and local regulators, and other stakeholders for evaluating the hydrologic effects of changing water-supply and wastewater-disposal practices on Cape Cod. Local-scale models also have been developed to investigate public-supply wells, ponds, and contaminant plumes in specific areas of concern (fig. 3). Many of the local-scale studies have focused on areas near the JBCC in support of environmental restoration efforts by the Department of Defense.

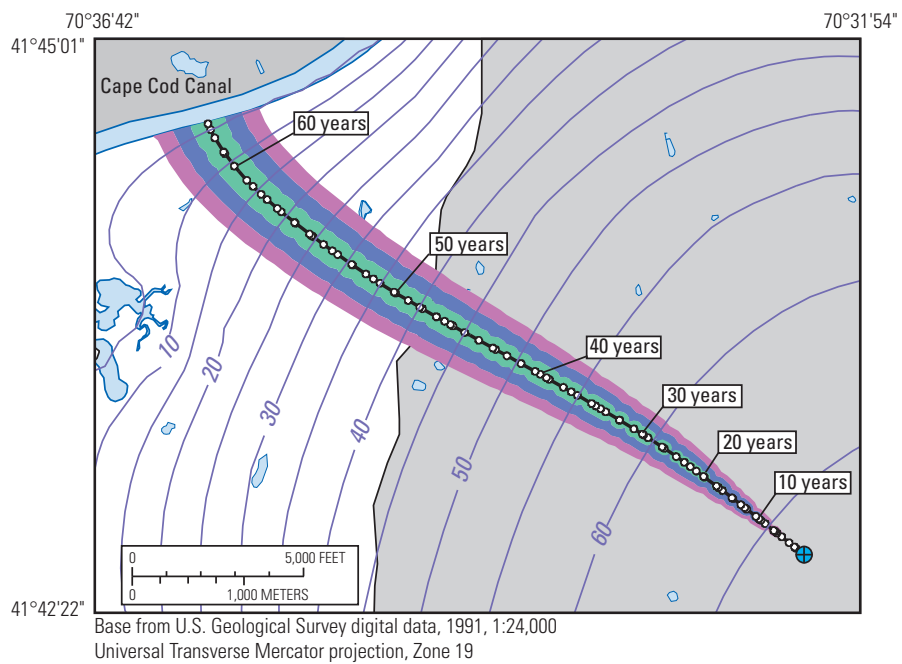

\section{EXPLANATION}

Areas of confidence

\begin{tabular}{|l|l}
\hline & Areas of confidence \\
& Area of 68-percent confidence \\
& Area of 95-percent confidence \\
& Area of 99 -percent confidence \\
\hline \hline & Joint Base Cape Cod \\
\hline$-20-$ Simulated line of equal water-table \\
altitude - Contour interval is 5 feet. \\
Datum is National Geodetic Vertical Datum of 1929 \\
$\quad$ Simulated particle track \\
\hline$\quad$ Simulated particle position \\
$\oplus \quad$ Soil contamination area
\end{tabular}

Figure 3. Simulated groundwater flow path from a known soil contamination area on the Joint Base Cape Cod toward a discharge area near the Cape Cod Canal, Massachusetts. Particles are used to visualize the trajectory of the simulated flow path. The colored bands represent confidence intervals associated with the simulated flow path. Figure modified from Walter and LeBlanc (2008). 
The USGS is currently [2014] using an extensive hydrologic dataset and the most recent generation of modeling tools to develop an updated regional groundwater-flow model of western Cape Cod. For improved development and calibration, the model also incorporates information on the locations of contaminant plumes on the JBCC. Simulations from this updated model could be used to investigate potential effects of plume restoration on contributing areas to public-supply wells in neighboring towns.

\section{Transport and Discharge of Nitrogen Derived From Wastewater Disposal}

Much of the densest development on Cape Cod is near the coast (fig. 4). As a result, coastal waters are at risk for eutrophication from excess nutrients originating onshore. Nitrogen is the nutrient of greatest concern for marine ecosystems. Excess nitrogen degrades water quality, reduces water clarity, increases the frequency of harmful algal blooms, and results in the loss of marine habitat (fig. 5). Resource managers and citizens are increasingly concerned about eutrophication and habitat loss in coastal waters, which are ecologically, recreationally, and economically important. Excess nitrogen in groundwater can also adversely affect drinking-water supplies.

Wastewater is the largest source of nitrogen in developed areas. Many towns with dense residential development rely on septic systems for wastewater disposal, and some of these communities are considering wastewater-management plans that involve sewering and centralized disposal of treated wastewater. The USGS has used hydrologic data and groundwater models to investigate nitrogen transport to public-supply wells and natural discharge areas at a variety of spatial scales and locations on Cape Cod. Regional models for central and western Cape Cod have been used to determine wastewater traveltimes from source areas to wells and sensitive ecological receptors, such as streams, ponds, and coastal waters, to estimate rates of wastewater discharge to these receptors, and to evaluate the effects of possible wastewater-disposal scenarios for addressing excess groundwater nitrogen. These modeling studies generally show that nitrogen discharge to sensitive receptors can be reduced by effective wastewater-disposal planning. However, because groundwater traveltimes between recharge and discharge areas can exceed 100 years on Cape Cod, a long time can elapse before the effects of management actions become evident.

On a local scale, studies have investigated the transport and discharge of nitrogen to individual salt marshes and estuaries on Cape Cod, including protected areas in the Cape Cod National Seashore (fig. 1). Local studies can examine in detail the biogeochemical reactions that increase or decrease nitrogen concentrations along groundwater flow paths and at interfaces of groundwater and surface water. The USGS and the U.S. Environmental Protection Agency are jointly investigating [2014] the transport of nitrogen derived from onsite septic systems to several saltwater embayments in Falmouth, Massachusetts (fig. 4). The objective of the study is to develop a better understanding of the effects of nitrogen discharge from residential wastewater-disposal systems on coastal waters.

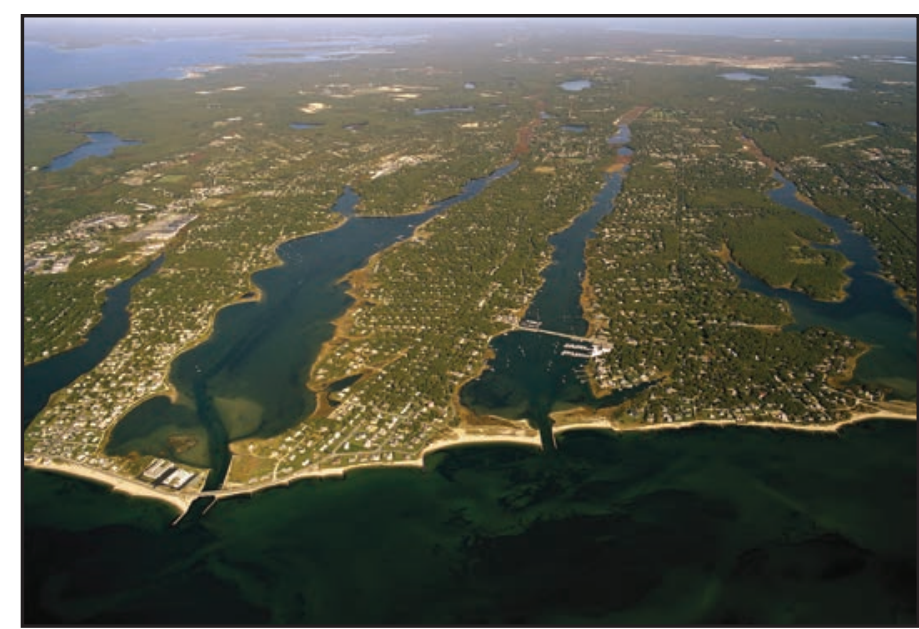

Figure 4. Coastal development in Falmouth, Massachusetts. Residential septic systems and lawn fertilization in this densely populated area have produced high concentrations of nitrogen in groundwater and coastal waters. Photograph by Joseph R. Melanson, Aerials Only (http://www.skypic.com/), used with permission.

\section{Effects of Climate Change on Groundwater Resources}

The potential effects of climate change are of particular concern on Cape Cod with its extensive coastline and fresh groundwater-flow systems underlain by saltwater (fig. 6). Current estimates are that by 2100 the sea level could be about 1 to 6 feet higher than the current sea-level position, and precipitation rates in the northeastern United States could increase by as much as 20 percent (Massachusetts Executive Office of Energy and Environmental Affairs, 2011). Although researchers and other stakeholders have focused much attention on increased rates of shoreline erosion and flooding from severe coastal storms and inundation of coastal areas, less consideration has been given to the potentially widespread effects of changes in

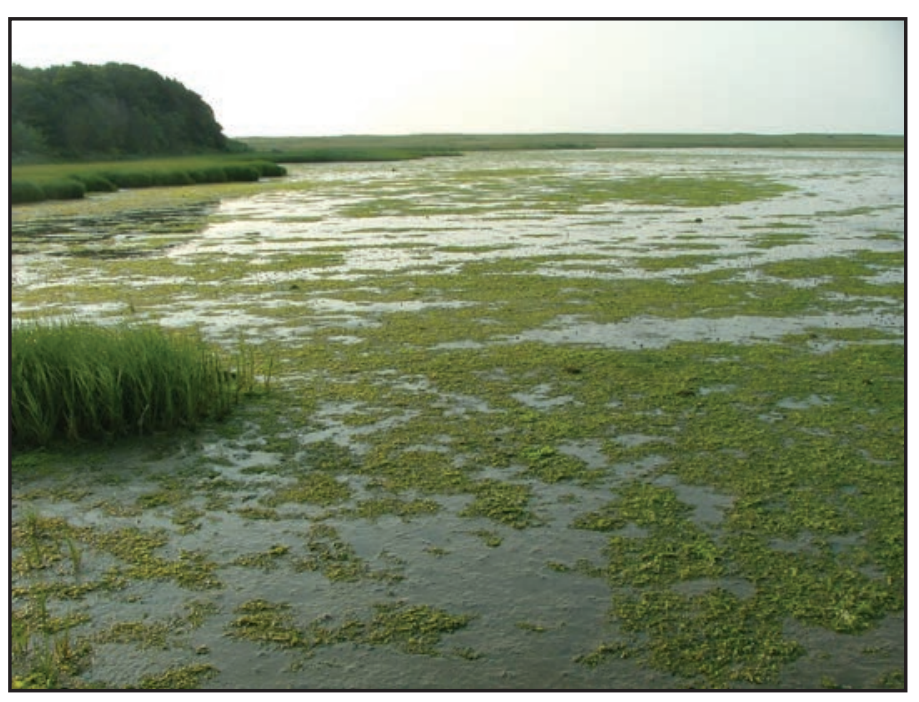

Figure 5. Algal growth in Nauset Bay, Cape Cod National Seashore, Eastham, Massachusetts. Residential septic systems are a major source of excess nitrogen in the groundwater that discharges to the bay. Photograph by John Colman, USGS, 2005. 


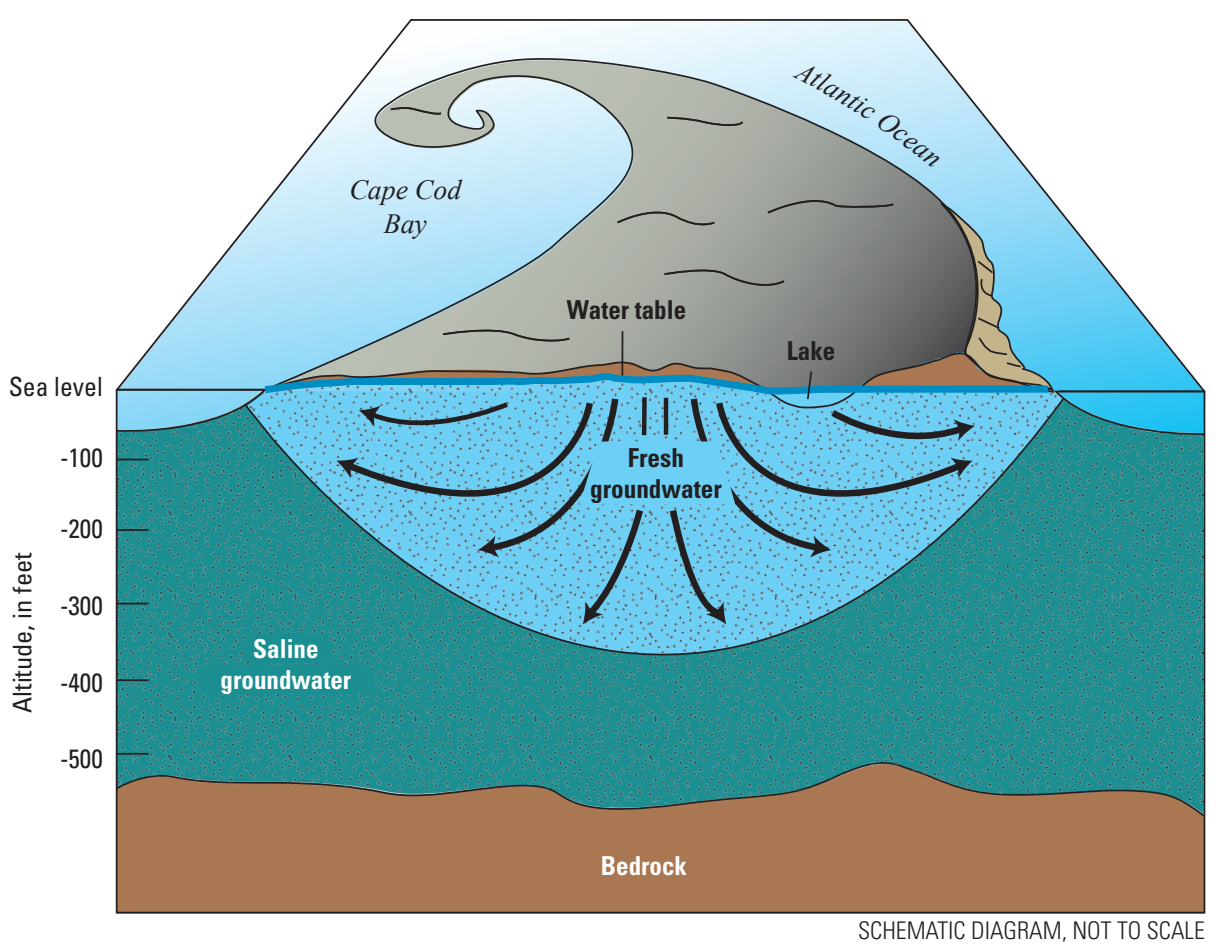

Figure 6. Schematic diagram of the groundwater-flow system on the outer part of Cape Cod, Massachusetts, where fresh groundwater is underlain by saline groundwater. On the inner part of Cape Cod, closer to the mainland, fresh groundwater extends to the bedrock surface, and the interface between freshwater and saltwater is confined to areas near the coast. Modified from Masterson and Walter (2009). sea level and aquifer recharge on the water resources of coastal aquifers, including areas well inland from the coast. Potential effects of changes in sea level and aquifer recharge include the loss of potable water supplies from increased saltwater intrusion into the aquifer; subsurface flooding of infrastructure, including septic systems, from an increase in the height of the underlying water table (fig. 7); and potentially detrimental changes to freshwater habitats in low-lying areas.

Recent USGS studies have focused on changes in the groundwater-flow system and the position of the interface between freshwater and saltwater that can result from future changes in sea level. Preliminary analyses based on regional groundwater-flow modeling indicate that rising sea levels will result in increases in water-table heights inland from the shoreline, increases in groundwater discharge to streams, and saltwater intrusion into coastal aquifers. As the potential effects of climate change on precipitation and sea-level rise in the

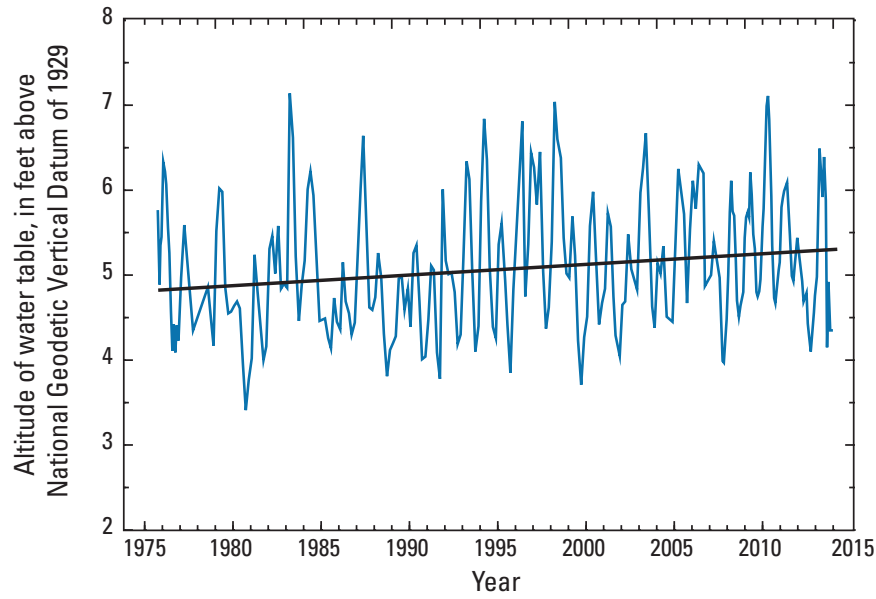

Northeast are better understood, future studies incorporating climate-change predictions will be able to provide more reliable assessments of the effects of climate change on groundwater resources on Cape Cod. Such assessments will be important for the development of strategies for adapting to the effects of sea-level rise.

\section{Groundwater Contamination Research at the Cape Cod Toxic Substances Hydrology Research Site}

The Cape Cod Toxic Substances Hydrology Research Site is near the former wastewater-treatment facility at the JBCC. A plume of treated wastewater originates from the facility's infiltration beds, which were used from 1936 through 1995 (fig. 8 ). The plume extends nearly 4.5 miles from the disposal site in the sand and gravel aquifer and contains a complex mixture of phosphate, nitrate, metal ions, detergents, and other organic

Figure 7. Water-table altitude at U.S. Geological Survey observation well MA-PZW 78, Provincetown, Massachusetts, from 1975 through 2013. Water levels (shown by the blue line on the graph) have risen at an average rate of about 0.15 inch per year since 1975, possibly as a result of sea-level rise. The well is 4,300 feet from Cape Cod Bay. The trend line is a linear fit to monthly groundwater-level data. 
compounds. The wastewater plume and the surrounding aquifer serve as an ideal field laboratory for investigating contaminant transport in groundwater.

Knowledge gained from research at the Cape Cod Toxic Substances Hydrology Research Site is used widely by waterresource managers, regulators, educators, and scientists.

Research results and field methods developed during more than 30 years by the USGS and other scientists studying the wastewater plume and surrounding aquifer also have been applied to other groundwater investigations on Cape Cod, including investigations of the reactive transport of other contaminant plumes on the JBCC, the fate of pharmaceutical and personal care products in groundwater, and the discharge of nutrient-rich groundwater to freshwater ponds and saline coastal waters (fig. 9).

\section{Long-Term Water-Level Monitoring}

Long-term records of water levels have been invaluable for developing a better understanding of the dynamics of the hydrologic system on Cape Cod and documenting long-term trends in groundwater and pond levels. In areas not affected by pumping or wastewater discharge, long-term data can be used to determine whether groundwater levels are responding to changes in climate (fig. 7). Long-term records also provide

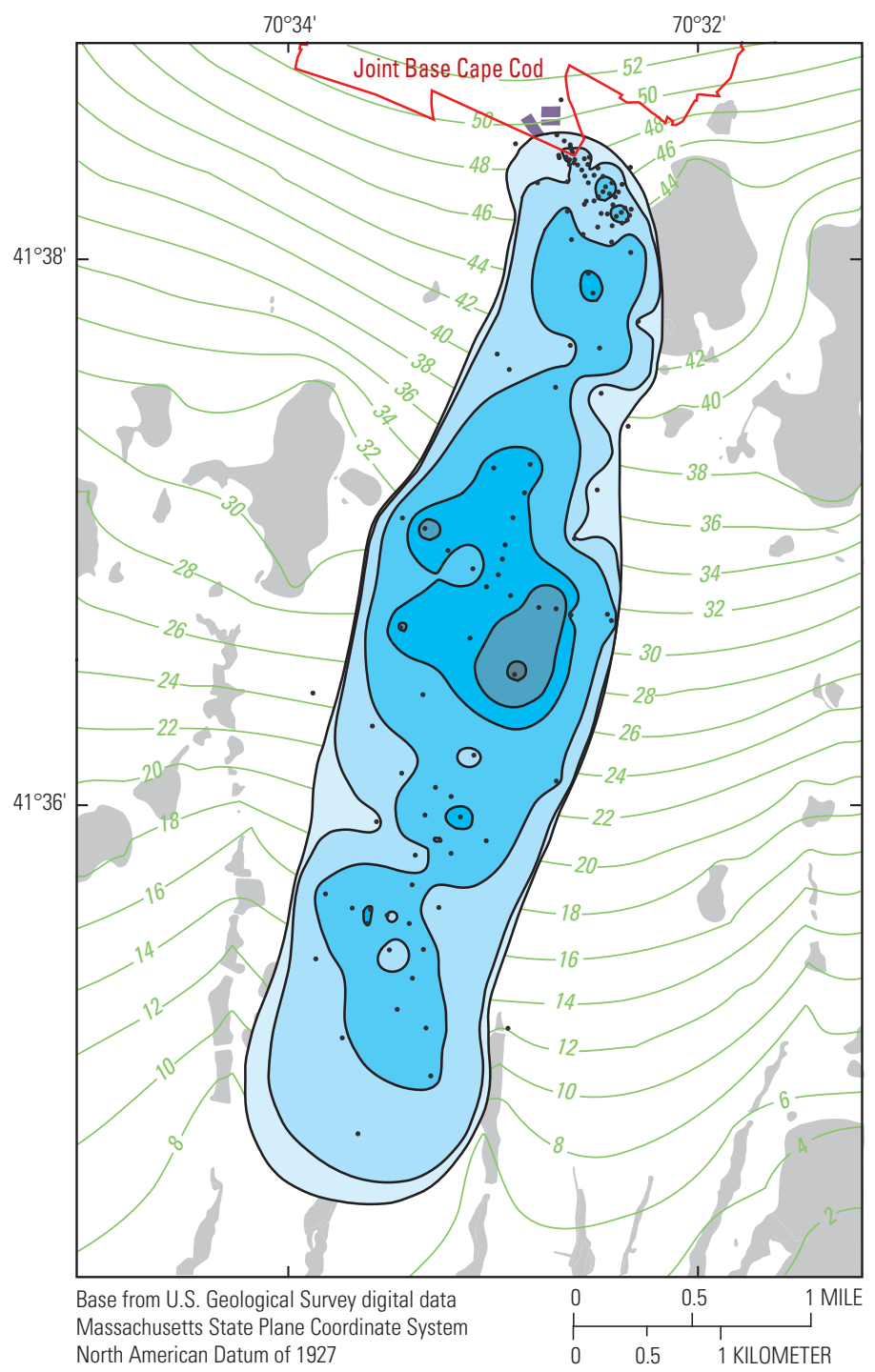

estimates of water levels that are lower and higher than average that can be expected during droughts and wet periods. These records have helped in the proper design of septic systems. The historical water-level data are also a critical input in the calibration of groundwater-flow models that enable predictive analysis of the response of the groundwater system to future changes in land use and climate.

Since the mid-1960s, the USGS and its partners at the Cape Cod Commission (CCC), the Association to Preserve Cape Cod (APCC), the Massachusetts Departments of Environmental Protection and Conservation and Recreation, and the National Park Service have monitored water levels in wells and ponds on Cape Cod. The original mid-1960s network of about 13 wells was supplemented in the mid-1970s with 12 ponds monitored by APCC volunteers (through about 2000) and 40 wells monitored by the CCC (ongoing). In the early 2000s, the USGS began monitoring water levels in 5 additional wells and 1 pond with support from the environmental cleanup agencies at the JBCC. Water levels are measured monthly to continuously in the wells and ponds (http://groundwaterwatch.usgs.gov/ StateMaps $(M A . h t m l)$. Water-level data are used widely by the water-resources community, including resource managers, State and local regulators, educators, and scientists.

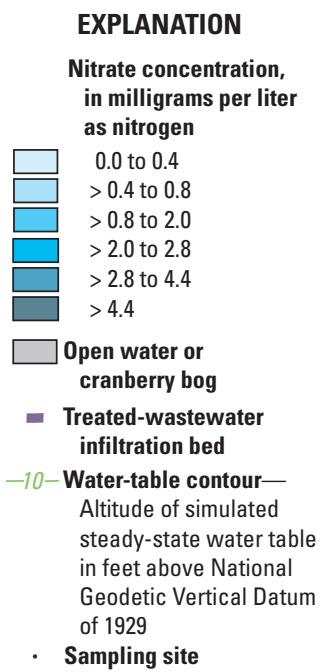

Figure 8. The nitrate plume created by 60 years of treated wastewater disposal on Joint Base Cape Cod. The plume, shown here at 55 feet below sea level, was approximately 4.5 miles in length and near areas of coastal discharge in 2007. Figure modified from Barbaro and others (2013). 


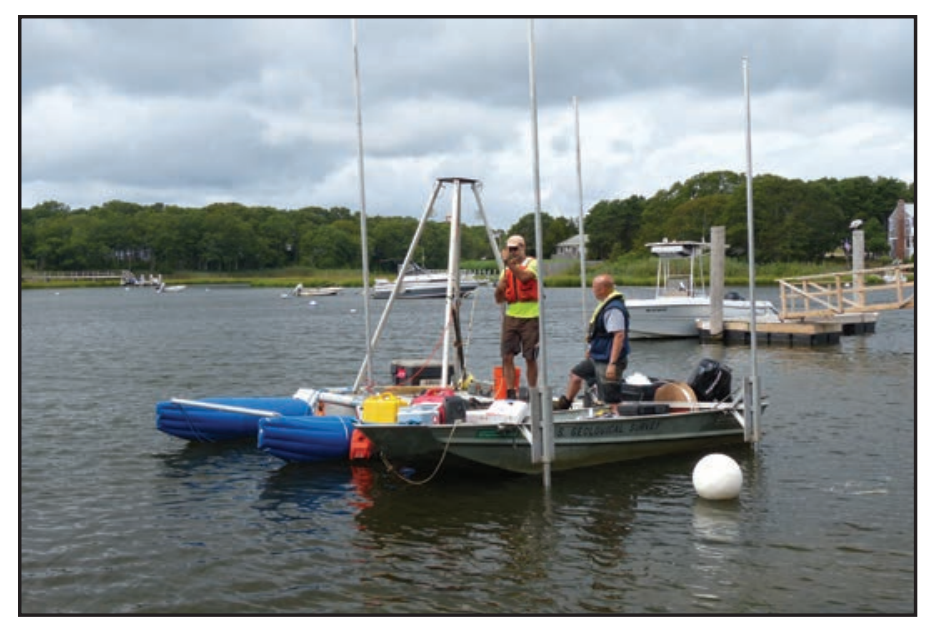

Figure 9. U.S. Geological Survey (USGS) field team collecting samples to measure concentrations of nitrogen in shallow groundwater discharging to Eel Pond, Falmouth, Massachusetts. Photograph by Denis LeBlanc, USGS, 2013.

\section{Acknowledgments}

Major funding for the studies described in this fact sheet was provided by the National Park Service, the U.S. Air Force and Army National Guard, the Massachusetts Departments of Environmental Protection and Conservation and Recreation, and the Cape Cod Commission. The authors also recognize the support and interest of many local and regional agencies and groups.

\section{Selected References}

Barbaro, J.R., Walter, D.A., and LeBlanc, D.R., 2013, Transport of nitrogen in a treated-wastewater plume to coastal discharge areas, Ashumet Valley, Cape Cod, Massachusetts: U.S. Geological Survey Scientific Investigations Report 2013-5061, 37 p., http://pubs.usgs.gov/sir/2013/5061/.

Colman, J.A., and Masterson, J.P., 2008, Transient simulations of nitrogen load for a coastal aquifer and embayment, Cape Cod, MA: Environmental Science \& Technology, v. 42, no. 1, p. 207-213, http://dx.doi.org/10.1021/es070638b.

Massachusetts Executive Office of Energy and Environmental Affairs, 2011, Massachusetts climate change adaptation report-September 2011: Massachusetts Executive Office of Energy and Environmental Affairs Web page, 121 p., accessed June 19, 2014, at http://www.mass.gov/eea/wastemgnt-recycling/air-quality/green-house-gas-and-climatechange/climate-change-adaptation/climate-change-adaptation-report.html.

Masterson, J.P., 2004, Simulated interaction between freshwater and saltwater and effects of ground-water pumping and sealevel change, Lower Cape Cod aquifer system, Massachusetts: U.S. Geological Survey Scientific Investigations Report 2004-5014, 72 p., http://pubs.usgs.gov/sir/2004/5014/.
Masterson, J.P., and Garabedian, S.P., 2007, Effects of sea-level rise on ground water flow in a coastal aquifer system: Ground Water, v. 45, no. 2, p. 209-217, http://dx.doi.org/10.1111/ j.1745-6584.2006.00279.x.

Masterson, J.P., and Walter, D.A., 2009, Hydrogeology and groundwater resources of the coastal aquifers of southeastern Massachusetts: U.S. Geological Survey Circular 1338, 16 p., http://pubs.usgs.gov/circ/circ1338/.

Walter, D.A., 2013, The simulated effects of wastewatermanagement actions on the hydrologic system and nitrogenloading rates to wells and ecological receptors, Popponesset Bay Watershed, Cape Cod, Massachusetts: U.S. Geological Survey Scientific Investigations Report 2013-5060, 62 p., http://pubs.usgs.gov/sir/2013/5060/.

Walter, D.A., and LeBlanc, D.R., 2008, Use of inverse-modeling methods to improve ground-water-model calibration and evaluate model-prediction uncertainty, Camp Edwards, Cape Cod, Massachusetts: U.S. Geological Survey Scientific Investigations Report 2007-5257, 57 p., http://pubs.usgs.gov/ sir/2007/5257/.

Walter, D.A., and Whealan, A.T., 2005, Simulated water sources and effects of pumping on surface and ground water, Sagamore and Monomoy flow lenses, Cape Cod, Massachusetts: U.S. Geological Survey Scientific Investigations Report 2004-5181, 85 p., http://pubs.usgs.gov/sir/2004/5181/.

\section{For additional information, contact:}

Office Chief

Massachusetts-Rhode Island Office

New England Water Science Center

U.S. Geological Survey

10 Bearfoot Road

Northborough, MA 01532

dc_ma@usgs.gov

or visit our Web site at

http://ma.water.usgs.gov

By Jeffrey R. Barbaro, John P. Masterson, and Denis R. LeBlanc

This fact sheet was prepared with support from the Toxic Substances Hydrology and Groundwater Resources Programs of the U.S. Geological Survey.

\section{Further information about the groundwater resources of Cape Cod is available at}

http://ma.water.usgs.gov/projects/capegwresources/ 